\title{
Collagen-The Skeleton of the Periodontium: A Review
}

Apoorva Sokke Mallikarjunappa ${ }^{1}$, Swati George ${ }^{2}$, Suchetha Aghanashini ${ }^{3}$, Divya Bhat ${ }^{4}$, Darshan B Mundinamane ${ }^{5}$, Sapna Nadiger 6

\begin{abstract}
Aim and objective: The fibers of the periodontal ligament are a structurally integrated unit of fibrous components mainly collagenous in nature and similar to the other supportive connective tissues. Collagen is the foremost abundant protein in mammals. Within the extracellular matrix, they form supramolecular assemblies with a minimum of one triple-helical domain.

Background:The collagen family comprises 28 members. The fibers of the periodontium play a role in the structural organization of the tissues, and contribute to its mechanical properties, by accommodating intensive forces from mastication and tooth eruption. They interact with cells via several receptor families and regulate their proliferation, migration, and differentiation. Certain collagens have a restricted tissue distribution and hence specific biological functions.

Review results: This review brings to light the synthesis, mineralization, and degradation of various types of collagen.

Conclusion: Collagen serves immense functions related to the structural integrity as well in the tooth-eruption mechanism. It presents with a rapid turnover rate which along with its biochemical composition would thereby help in determining a pathological involvement causing periodontal destruction.
\end{abstract}

Keywords: Biochemistry, Collagen, Crimping, Degradation, Mechanical support, Mineralization, Sharpey's fibers.

Journal of Scientific Dentistry (2021): 10.5005/jp-journals-10083-0938

\section{INTRODUCTION}

The fibrous elements of the periodontium support it by providing tensile strength, whereas the ground substance dissipates the compressional forces. These components, seen in the electron microscope as an insoluble fibrillar network surrounded by a thixotropic gel, meet the functional requirements of tooth support and eruption. Collagen is the most abundant and is often presumed to be the most important in terms of tooth support. Collagen is a protein composed of various amino acids; mainly glycine, proline, hydroxylysine, and hydroxyproline. The collagen content in a tissue can be determined by its hydroxyproline content. The collagen is formed by packing together of individual tropocollagen molecules of approximately $5 \mu \mathrm{m}$ in diameter and termed as principal fibers, with the bulk being type I collagen.

\section{Classification of Collagen Types}

Olsen ${ }^{2}$ divided it into main groups Fibril collagen and FACIT Collagens.

Fibril collagens include collagen type I, III, and V. ${ }^{2}$

FACIT collagens are fibrils-associated collagens with interrupted triple helices, but it does not directly associate with the major band collagen fibrils (Vonder Mark et al., 1984). ${ }^{3}$

According to Kielty and Grant, ${ }^{4} 25$ different gene sequences have been discovered encoding for collagenous polypeptides giving rise to 13 distinct collagen types, which can be divided into three groups:

The first, most abundant group is the fibrous collagens. These are in the form of uninterrupted helices that are highly conservative and are mainly I, II, III, V, and XI. The second group is the high molecular weight collagen, comprising of numerous intervening non-helical sequences, in association with the basement membrane. Types IV and VII. The third group is a short-chain, nonhelical domain, and consists of types VI, VIII, IX, X, XII, and XIII. ${ }^{5-7}$

\footnotetext{
${ }^{1-6}$ Department of Periodontics, DAPMRV Dental College, Bengaluru, Karnataka, India
}

Corresponding Author: Swati George, Department of Periodontics, DAPMRV Dental College, Bengaluru, Karnataka, India, Phone: +91 9792174146, e-mail: swatigeorge@gmail.com

How to cite this article: Mallikarjunappa AS, George S, Aghanashini S, Bhat D, Mundinamane DB, Nadiger S. Collagen-The Skeleton of the Periodontium: A Review. J Sci Dent 2021;11(1):31-36.

Source of support: Nil

Conflict of interest: None

The main types of collagen in the periodontal ligament are type I and type III (Table 1).

\section{Type I Collagen}

It is the major protein component of most connective tissues. The biosynthesis and fibrillogenesis of type I collagen within PDL could be determined by studying its posttranslational modifications. ${ }^{8}$ It comprises two identical a1 chains and a $a 2$ chain which is low in hydroxylysine and glycosylated hydroxylysine. Collagen type II is a short-chain molecule that has only recently been located in the PDL (Romanos et al. .),

\section{Type III Collagen}

The periodontal ligament is rich in type III collagen (about 20\%) which is covalently linked to type I collagen relatively high in hydroxyproline and cysteine whereas low in hydroxylysine. It is found in the periphery of Sharpey's fiber attachments into the alveolar bone and around nerves and blood vessels, the function, however, is unknown. A higher proportion of collagen type III is present in fetal tissue (Berkowitz) ${ }^{5}$ and follows a similar distribution pattern with the major fibrils throughout the tissue. 
Table 1: Classification of collagen

\begin{tabular}{|c|c|c|}
\hline Class & Type & Distribution \\
\hline \multirow[t]{7}{*}{ Fibril-forming (fibrillar) } & 1 & Bone, skin, cornea, ligaments, tendon \\
\hline & II & Cartilage, vitreous humor in the eye \\
\hline & III & Skin, blood vessels \\
\hline & $\mathrm{V}$ & Bone, dermis, co-distribution with type I \\
\hline & $\mathrm{XI}$ & Cartilage, inverterbral discs, co-distribution with type II \\
\hline & XXIV & Bone, cornea \\
\hline & XXVII & Cartilage \\
\hline \multirow[t]{10}{*}{ Fibril-associated collagens with interrupted triple helices (FACIT) } & VII & Bladder, dermis \\
\hline & IX & Cartilage, cornea \\
\hline & XII & Tendon, dermis \\
\hline & XIV & Bone, dermis, cartilage \\
\hline & $\mathrm{XVI}$ & Kidney, dermis \\
\hline & $\mathrm{XIX}$ & Basement membrane \\
\hline & $X X$ & Cornea of chick \\
\hline & $X X I$ & Kidney, stomach \\
\hline & XXII & Tissue junctions \\
\hline & $\mathrm{XXVI}$ & Ovary, testis \\
\hline \multirow[t]{5}{*}{ Networking associated } & IV & Basement membrane \\
\hline & $\mathrm{VI}$ & Muscle, dermis, cornea, cartilage \\
\hline & VIII & Brain, skin, kidney, heart \\
\hline & $\mathrm{X}$ & Cartilage \\
\hline & XXVII & Dermis, Sciatic nerve \\
\hline \multirow[t]{4}{*}{ Membrane-associated collagens with interrupted triple helices (MACIT) } & XIII & Dermis, eyes, endothelial cells \\
\hline & $\mathrm{XVII}$ & Hemidesmosomes in epithelia \\
\hline & XXIII & Heart and retina \\
\hline & $X X V$ & Heart, testis brain \\
\hline \multirow[t]{2}{*}{ Multiple triple helix domains and interruptions (MULTIPLEXINs) } & $\mathrm{XV}$ & Capillaries, testis, heart, kidney \\
\hline & XVIII & Liver and basement membrane \\
\hline
\end{tabular}

\section{Other Types of Collagen}

Minute amounts of type IV, V, VI, and VII collagen have been found in the ligament. Type IV and VII collagen forms the major fraction of basal lamina protein of the blood vessels, ${ }^{9}$ the neurovascular bundles and epithelial rests of PDL. It does not form fibrils and helps maintain the structure and integrity of the PDL. ${ }^{10}$

Type $\mathrm{V}$ is believed to be associated with the cell surface and coats the type III and type I fibrils. Type VI is a component of oxytalan fibers though not directly associated with the major fibrils. It may play a role in maintaining the integrity and elasticity of the extracellular matrix (ECM). ${ }^{11}$

Type XII collagen helps organize the ECM architecture of dense connective tissues ${ }^{12}$ and occurs only when the ligament is fully functional. ${ }^{12,13}$ This type has an NC3 domain that carries glycosaminoglycan chains, and it interacts with matrix proteins such as decorin, cartilage oligomeric matrix protein, fibromodulin, and tenascin and could possibly be associated with the functional regeneration of the $\mathrm{PDL}^{14}$ (Table 2).

\section{General Structure of Fibrous Collagens}

All collagens are made up of three polypeptide chains organized into a triple-helical structure ${ }^{15}$ with a mean diameter of $45-55 \mathrm{~nm}$ and transverse striations with a characteristic periodicity of $64 \mathrm{~nm}$. Each polypeptide chain contains 1,056 amino acid residues, in the form of the repeating tri-residue Motif (Gly-x-y), (where $x$ is often proline and $y$ is often hydroxyproline) conferring its characteristic conformation. ${ }^{15-17}$

\section{General Biosynthesis of Fibrous Collagens}

Fessler et al. ${ }^{18}$ found the precursor to be "procollagen" synthesized from fibroblasts of tissue explants in vitro. Pro collagens possess a relative molecular mass greater than tropocollagen. They comprise peptide extensions on the $\mathrm{C}$ and $\mathrm{N}$ termini referred to as propeptides. Cleavage of those propeptides may be a necessary prerequisite for fibrillogenesis within the ECM. Schofield and Prockop ${ }^{19}$ at the pretranslational level.

\section{Synthesis of Procollagen}

The ribosomes on the rough endoplasmic reticulum (RER) initiates the biosynthesis of procollagen involving extensive cotranslation and posttranslational modifications controlled by various enzymes. ${ }^{20}$ Conversion from procollagen to collagen is a specific process. ${ }^{21}$ Peltonen et al. proposed that the cleavage of the carboxy-terminal propeptides of types I and III are differently affected by lysine. ${ }^{22}$

\section{Hydroxylation of Proline and Lysine}

Hydroxylation of PRO and LYS residues is a cotransitional event occurring during chain elongation at the ribosome. ${ }^{21}$ Its cross-linking is based upon aldehyde formation from specific telopeptides, Knott and Bailey ${ }^{23}$ catalyzed by three hydroxylase 
Table 2: Ultrastructural distribution of collagen fibers

\begin{tabular}{|c|c|c|c|}
\hline & Tissue distribution & Supramolecular organization & Associations \\
\hline Collagen type I & Interstitium & $\begin{array}{l}\text { Cross-banded fibers; diameters } \\
\cong 30-35 \mathrm{~nm} \text {; banding interval } \cong \\
64 \mathrm{~nm}\end{array}$ & $\begin{array}{l}\text { Basic structural component associ- } \\
\text { ated with collagen types III, V, VI, and } \\
\text { fibronectin }\end{array}$ \\
\hline Collagen type III & Interstitium & $\begin{array}{l}\text { Beaded fibers; diameter } \cong 15-20 \\
\mathrm{~nm} \text {; beaded interval } \cong 40-64 \mathrm{~nm}\end{array}$ & $\begin{array}{l}\text { Associated with other interstitial collagens } \\
\text { and fibronectin }\end{array}$ \\
\hline Collagen type V & Interstitium & Thin filaments $\cong 10 \mathrm{~nm}$ & $\begin{array}{l}\text { Associated with types I and III often } \\
\text { extending to this interstitial aspect of } \\
\text { vascular basement membranes }\end{array}$ \\
\hline Collagen type VI & Interstitium & Thin filaments $\cong 10 \mathrm{~nm}$ & $\begin{array}{l}\text { Associated with types I and III often } \\
\text { extending to this interstitial aspect of } \\
\text { basement membranes }\end{array}$ \\
\hline Fibronectin & Interstitium and plasma & $\begin{array}{l}\text { Thin filaments and glomerular } \\
\text { aggregates diameter } \cong 10 \mathrm{~nm}\end{array}$ & Associated with interstitial collagen \\
\hline Laminin & $\begin{array}{l}\text { Basement membranes both laminae but } \\
\text { preferentially in the lamina rare }\end{array}$ & Not resolved & Associated with type IV collagen \\
\hline Collagen type IV & $\begin{array}{l}\text { Basement membrane both laminae but } \\
\text { preferentially in the lamina densa }\end{array}$ & Not resolved & Associated with laminin \\
\hline
\end{tabular}

enzymes which require $\mathrm{Fe}^{2+}$, a-ketoglutarate, $\mathrm{O}_{2}$, and ascorbic acid. ${ }^{19,20}$ This, however, ceases after triple-helix formation.

The role of hydroxyproline and hydroxylysine in helix stability and cross-linkage is of prime importance and a failure results in a range of pathologies ${ }^{22}$ such as scurvy, and Menkes' Kinky hair syndrome. The varied rates of PDL destruction amongst individuals speculate of distinctive lysine/hydroxylysine cross-linking variations in collagen. ${ }^{23}$

\section{Glycosylation of Hydroxylysine and Asparagine}

Glycosylation reactions are catalyzed by hydroxylysyl galactosyltransferase and galactosyl hydroxylysyl glucosyltransferase and its amount varies with age and the type of tissue. Yamauchi and Sricholpech provided an overview on the enzymatic lysine modifications and subsequent cross-linking to form covalent intraand inter-molecular cross-links. ${ }^{24}$

\section{Helix Formation}

Triple helix formation is initiated via the association of the three C-terminal propeptides, ${ }^{25}$ whereas chain alignment begins by noncovalent (hydrophobic) interactions at the C-terminal propeptide (Fessler et al.). ${ }^{18}$ The rate-determining step for helix formation is the stabilization of the alignment by disulfide bonds in the propeptides (Freedman) ${ }^{26}$ catalyzed by disulfide isomerase (Freedman and Hillson). ${ }^{27}$ Subsequently, the folding of the triple helix proceeds rapidly. The procollagen molecule is then exported via the Golgi apparatus in the classical secretory pathway, further processing occurs by endopeptidases to form tropocollagen aggregates. The elimination of the propeptidases is achieved by enzymes belonging to the class of matrix metalloproteinases. ${ }^{5}$

\section{Collagen Crimping}

Collagenous tissues exhibit a quantifiable periodicity of the structure of variable scale; ranging from submicroscopic to anatomical; sinusoidal waveform. ${ }^{28,29}$ This has been referred to as "crimp" (Diamant et al., Gathercole). ${ }^{30,31}$ It was suggested that the developing fibroblastic processes help fabricate the crimped structure, thus a prerequisite in tooth eruption (Gathercole and Keller). ${ }^{31}$
Crimping can be recognized by a regular banding of dark lines across a collagenous bundle in polarizing microscopes, biomechanical studies, and X-ray diffraction analysis (Keller and Gathercole and Keller). ${ }^{31,32}$ Crimping may either be due to the arrangement of collagen fibrils or due to the microanatomical organization of collagenous sheets and bundles (Gathercole and Keller). ${ }^{31}$ SEM observations demonstrate the intertwining of fibrils with one another and in the outer region. ${ }^{33}$ Birefringence studies reported no evidence of fiber directional dispersions (Kolenda and Serwa et al., 2018). ${ }^{34}$

\section{Sharpey's Fibers}

Sharpey's fibers (SF) are poorly mineralized fibers of the animal tissue, composed mostly of several sorts of collagen, elastin, or tenascin ${ }^{35-37}$ embedded into the cementum and alveolar bone and concentrated within the crestal region ${ }^{38,39}$ in various orientation. ${ }^{37}$

Light microscopic observations suggest their continuity with the periodontal ligament of adjacent teeth. On the premise of ultrastructural and microradiographic observations, Selvig 1965 has reported that Sharpey's fibers have unmineralized cores and are separated by lamellar bone fibers which are either randomly arranged or are parallel to the mineral surface. ${ }^{40}$ Immunohistochemistry reveals that Sharpey's fibers are enclosed within a sheath of collagen type III conferring elasticity and preventing remineralization. ${ }^{41}$ Scanning electron microscopy shows that the peripheral bone surrounding the Sharpey's fibers may be mineralized to a level slightly above or below the level of the bone surface and exhibit a stippled appearance that indicates that the mineralization occurs approximately at right angles to the axis of the fibers ${ }^{42}$ and this offers a mechanical advantage for transmitting axially directed forces and tensional forces. ${ }^{43}$ The amount and ratio of collagenous protein in the Sharpey's fibers and adjacent alveolar bone, gets affected by the intensity and characteristics of the orthodontic movements. ${ }^{44}$

\section{Mineralization of Collagen}

Collagen fibers are mineralized along their length and cores with hydroxyapatite crystals. ${ }^{45} \mathrm{~A}$ well-defined interface is present between the mineralized and non-mineralized collagen within the PDL which implies a mechanism that retains the 
width (approximately 200 pm within the case of human PDL) of unmineralized fibers. Sharpey's fibers represent an embedding of the PDL fibers by entrapment in the advancing mineral front. ${ }^{40,46}$

Collagen mineralization may be mediated by restriction enzymes such as alkaline phosphatase located in the bulk of the tissue adjacent to the alveolar bone. Several causes may lead to the failure of the mineralization of the PDL fibers. Cross linkage of PDL fibrils could lead to restriction of access of minerals to its nucleation sites, thereby affecting the glycosylation of collagen, its assembly, and the proteoglycans. ${ }^{5,34,47}$

\section{General Features of Collagen Degradation}

In the event of morphogenesis, the collagen undergoes breakdown thus maintaining a balance between its degradation and synthesis.

Collagen degradation is primarily associated with two mechanisms:

- Various cells (fibroblasts, PMNs, and macrophages) in the healthy or inflamed tissues secrete collagenases and other enzymes; (which degrade collagen and other matrix macromolecules into small peptides are called matrix metalloproteinases) destroy collagen extracellularly.

- Secondly, fibroblasts degrade collagen fibers by phagocytosis. Cytoplasmic processes of the fibroblasts extend to the ligamentcementum interface and thereby degrade the inserted collagen fibrils and the fibrils of the cementum matrix. ${ }^{1,5,6,7,48}$

The collagen breakdown is mediated via matrix metalloproteinases - a group of zinc-containing endopeptidases characterized by their metal-binding properties, and secreted as inactive precursors, and inhibited by tissue inhibitor of metalloproteinases (TIMP).

MMPs are predominantly secreted by fibroblasts and also produced by some leukocytes (polymorphonuclear neutrophil leukocytes and macrophages). Six major matrix metalloproteases are effective in collagen degradation. Matrix metalloproteinases are also known to be inducible enzymes, and the cytokines, particularly interleukin-1, seem to play an important role in the control of their expression. ${ }^{49}$

The triple helix fibrillar collagen though resistant to proteolytic degradation ${ }^{50}$ loses its conformation after cleavage, resulting in a denatured molecule exposed to less specific proteases. The regulation of MMP's is important for the maintenance of tissue morphostasis. The primary control is exerted by the production of the inhibitor molecule. ${ }^{51}$ Tissue inhibitor of metalloproteinases is a glycoprotein secreted by fibroblasts and macrophages. Tissue inhibitor of metalloproteinases forms an irreversible complex with the MMPs via non-covalent interactions. TGFB also increases TIMP production.

These can be further degraded by lysosomal enzymes (notably cysteine proteases), which operate at acidic pHs. In contrast to the extracellular degradation of collagen, is an intracellular pathway of collagen phagocytosis and subsequent breakdown does not appear to involve matrix metalloproteinases. ${ }^{52-55}$ Glucocorticoids and retinoids inhibit MMP production ${ }^{56-58}$ and simultaneously increase the production of TIMP (Table 3).

\section{ConcLusion}

The major fibrous protein of the PDL is type I collagen, with type III collagen present in unusually high quantities (about $20 \%$ of collagen present). Types IV, V, VI, and XII have also been detected,
Table 3: Matrix metalloproteinases and collagen remodeling

\begin{tabular}{|c|c|c|c|}
\hline Enzyme & $M M P$ & Substrate & Other substrates \\
\hline \multicolumn{4}{|l|}{ Collagenases } \\
\hline Collagenase-1 & MMP-1 & $\begin{array}{l}\text { I, II, III, VII, X } \\
\text { (VIII, XI) }\end{array}$ & Gelatin \\
\hline Collagenase-2 & MMP-8 & $\begin{array}{l}\text { I, II, III (VII, VIII, } \\
X)\end{array}$ & $\begin{array}{l}\text { Aggrecan and } \\
\text { gelatin }\end{array}$ \\
\hline Collagenase-3 & MMP-13 & $\begin{array}{l}\text { I, II, III (IV, VI, X, } \\
\text { XIV) }\end{array}$ & Gelatin \\
\hline \multicolumn{4}{|l|}{ Gelatinases } \\
\hline Gelatinase-A & MMP-2 & $\begin{array}{l}\text { I, IV, V, VII, X (II, } \\
\text { III, X) }\end{array}$ & Gelatin \\
\hline Gelatinase-A & MMP-9 & IV, V, XIV (XI) & Gelatin \\
\hline \multicolumn{4}{|l|}{ Stromelysins } \\
\hline Stromelysin-1 & MMP-3 & $\begin{array}{l}\text { III, IV, XI, X (II, } \\
\text { VII, XI) }\end{array}$ & Gelatin \\
\hline Stromelysin-2 & MMP-10 & IV $(I I I, V)$ & $\begin{array}{l}\text { Laminin, } \\
\text { fibronectin, elastin }\end{array}$ \\
\hline Stromelysin-3 & MMP-11 & IV & $\begin{array}{l}\text { Laminin, } \\
\text { fibronectin, } \\
\text { aggrecan }\end{array}$ \\
\hline \multicolumn{4}{|l|}{ Matrilysins } \\
\hline Matrilysin-1 & MMP-7 & $\mathrm{IV}(\mathrm{I})$ & $\begin{array}{l}\text { Laminin, } \\
\text { fibronectin, gelatin }\end{array}$ \\
\hline Matrilysin-2 & MMP-26 & IV & $\begin{array}{l}\text { Fibrinogen, } \\
\text { fibronectin, gelatin }\end{array}$ \\
\hline \multicolumn{4}{|c|}{ Membrane type MMPs } \\
\hline MT1-MMP & MMP-14 & $\begin{array}{l}\text { I, II, III (and } \\
\text { proMMP-2) } \\
\text { general (and } \\
\text { proMMP-2) }\end{array}$ & $\begin{array}{l}\text { Laminin, } \\
\text { fibronectin, gelatin }\end{array}$ \\
\hline MT2-MMP & MMP-15 & III & $\begin{array}{l}\text { Laminin, } \\
\text { fibronectin, gelatin }\end{array}$ \\
\hline MT3-MMP & MMP-16 & & $\begin{array}{l}\text { Laminin, } \\
\text { fibronectin, gelatin }\end{array}$ \\
\hline MT4-MMP & MMP-17 & & Fibrinogen, fibrin \\
\hline MT5-MMP & MMP-24 & & $\begin{array}{l}\text { Laminin, } \\
\text { fibronectin, gelatin }\end{array}$ \\
\hline MT6-MMP & MMP-25 & IV & Gelatin \\
\hline \multicolumn{4}{|l|}{ Others } \\
\hline $\begin{array}{l}\text { Macrophage } \\
\text { metalloelastase }\end{array}$ & MMP-12 & $\mathrm{I}, \mathrm{IV}$ & Elastin, fibronectin \\
\hline Enamelysin & MMP-19 & IV & $\begin{array}{l}\text { Aggrecan, elastin, } \\
\text { fibrillin, gelatin }\end{array}$ \\
\hline \multirow[t]{3}{*}{ XMMP } & MMP-20 & & Aggrecan \\
\hline & MMP-21 & & Aggrecan \\
\hline & MMP-23 & & $\begin{array}{l}\text { Gelatin, casein, } \\
\text { fibronectin }\end{array}$ \\
\hline CMMP & MMP-27 & Unknown & Unknown \\
\hline Epilysin & MMP-28 & Unknown & Unknown \\
\hline
\end{tabular}

albeit in much smaller amounts. Periodontal ligament collagen is unusual in its supermolecular arrangement, rapid assimilation into fibrils with an absence of non-reducible cross-links with age and as compared with other soft connective tissues. ${ }^{59}$ This results in an extremely rapid rate of collagen turnover in the ligament. Collagen degradation is mediated by interstitial collagenase. 
Whereas increased collagenase activity appears to be associated with chronic inflammatory periodontal disease and could be cytokine-mediated.

The biochemistry of the fibers of the collagen of the PDL suggests that this is an unusual connective tissue, with many fetal-like characteristics. This may be related to tissue function and may represent an important factor in the etiology of chronic inflammatory periodontal disease.

\section{References}

1. Sloan P, Carter DH, Kielty CM, Shuttleworth CA. An immunohistochemical study examining the role of collagen type VI in rodent periodontal ligament. Histochem J 1993;25(7):523-530. DOI: 10.1007/BF00159289.

2. Olsen BR. The next frontier: molecular biology of extracellular matrix. Connect Tissue Res 1989;3(2-3):115-121. DOI: 10.3109/03008208909002411.

3. Berkowitz BKB, Moxham BJ, Newman HN. The periodontal ligament in health and disease. 2nd ed. Eur J Orthod 1996;8(6):670-671. DOI: 10.1093/ejo/18.6.670.

4. Kielty C, Grant M. The collagen family: structure, assembly, and organization in the extracellular matrix. Royce PM, Steinmann B eds. 2003 pp. 159-221. DOI: 10.1002/0471221929.ch2.

5. vonder Mark H, Aumailley M, Wick G, Fleischmajer R, Timpl R. Immunochemistry, genuine size and tissue localization of collagen VI. Eur J Biochem 1984;142:493-502

6. Nanci A, Ten Cate AR. Ten Cate's oral histology: development, structure, and function. St. Louis, Mo: Elsevier; 2013.

7. Kumar GS, Jha AK, Goswami N, Sahu SK, Kumar R, Tayaar AS. Orban's oral histology and embryology. Elsevier; 2011.

8. Kaku M, Yamauchi M. Mechano-regulation of collagen biosynthesis in periodontal ligament. J Prosthodont Res 2014;58(4):193-207. DOl: 10.1016/j.jpor.2014.08.003.

9. Li C, Fan M, Tang Z. Detection of types I, III and IV collagen in human cementum, periodontal ligament and alveolar bone. Zhonghua Kou Qiang Yi Xue Za Zhi 1997;32(2):70-72.

10. Everts V, Niehof A, Jansen D, Beertsen W. Type VI collagen is associated with microfibrils and oxytalan fibers in the extracellular matrix of periodontium, mesenterium and periosteum. J Periodontal Res 1998;33(2):118-125. DOI: 10.1111/j.1600-0765.1998.tb02300.x.

11. Reichenberger E, Baur S, Sukotjo C, Olsen BR, Karimbux NY, Nishimura I. Collagen XII mutation disrupts matrix structure of periodontal ligament and skin. J Dent Res 2000;79(12):1962-1968. DOI: 10.1177/00220345000790120701T.

12. Manon-Jensen T, Karsdal MA. Type XII collagen. In: Biochemistry of collagens, laminins and elastin: structure, function and biomarkers. 1st ed., Cambridge, MA, USA: Academic Press; 2016. pp. 81-85.

13. Zvackova I, Matalova E, Lesot $\mathrm{H}$. Regulators of collagen fibrillogenesis during molar development in the ouse. Front Physiol 2017;8:554. DOI: 10.3389/fphys.2017.00554.

14. Karimbux NY, Nishimura I. Temporal and spatial expressions of type XII collagen in the remodeling periodontal ligament during experimental tooth movement. J Dent Res 1995;74(1):313-318. DOI: $10.1177 / 00220345950740010501$.

15. Ramachandran GN, Ramakrishnan C, Sasisekharan V. Stereochemistry of polypeptide chain configurations. J Mol Biol 1963;7(1):95-99. DOI: 10.1016/s0022-2836(63)80023-6.

16. Ramachandran GN, Mitra AK. An explanation for the rare occurrence of cis peptide units in proteins and polypeptides. J Mol Biol 1976;107(1):85-92. DOI: 10.1016/s0022-2836(76)80019-8.

17. Lodish H, Berk A, Zipursky SL, Matsudaira P, Baltimore D, Darnell J. Molecular cell biology. 4th ed., New York: WH Freeman; 2000. Available from: https://www.ncbi.nlm.nih.gov/books/NBK21475/.

18. Fessler JH, Doege KJ, Duncan KG, Fessler LI. Biosynthesis of collagen. J Cell Biochem 1985;28(1):31-37. DOI: 10.1002/jcb.240280106.
19. Schofield JD, Prockop DJ. Procollagen-a precursor form of collagen. Clin Orthop Relat Res 1973(97):175-195. DOI: 10.1097/00003086197311000-00026.

20. Ahuja T, Dhakray V, Mittal M, Khanna P, Yadav B, Jain M. Role of collagen in the periodontal ligament - a review. Int J Microbiol 2012;10(1).

21. Kivirikko KI, Myllylä R. Post-translational processing of procollagens. Ann N Y Acad Sci 1985;460(1):187-201. DOI: 10.1111/j.1749-6632.1985. tb51167.x.

22. Peltonen $L$, Halila R, Ryhänen L. Enzymes converting procollagens to collagens. J Cell Biochem 1985;28(1):15-21. DOI: 10.1002/ jcb.240280104.

23. Knott L, Bailey AJ. Collagen cross-links in mineralizing tissues: a review of their chemistry, function, and clinical relevance. Bone 1998;22(3):181-187. DOI: 10.1016/s8756-3282(97)00279-2.

24. Hudson DM, Garibov M, Dixon DR, Popowics T, Eyre DR. Distinct posttranslational features of type I collagen are conserved in mouse and human periodontal ligament. J Periodontal Res 2017;52(6):1042-1049. DOI: 10.1111/jre.12475.

25. Yamauchi M, Sricholpech M. Lysine post-translational modifications of collagen. Essays Biochem 2012;52:113-133. DOI: 10.1042/ bse0520113.

26. Freedman RB, Hirst TR, Tuite MF. Protein disulphide isomerase: Building bridges in protein folding. Trends Biochemistry Sci 1994;19:331-336.

27. Creighton TE, Hilson DA, Freedman RB. Catalysis by proteindisulphide isomerase of the unfolding and refolding of proteins with disulphide bonds J Mol Biol 1980;142:43-62

28. Kirk JM, Bateman ED, Haslam PL, Laurent GJ, Turner-Warwick M. Serum type III procollagen peptide concentration in cryptogenic fibrosing alveolitis and its clinical relevance. Thorax 1984;39(10):726-732. DOI: 10.1136/thx.39.10.726.

29. Viidik A. Interdependence between structure and function in collagenous tissues. In: Viidik A, Vuust J, ed. Biology of collagen. London: Academic Press; 1980. pp. 257-280.

30. Diamant J, Andrew K, Baer E, Litt M, Arridge RGC. Collagen; ultrastructure and its relation to mechanical properties as a function of ageing. Proc R Soc Lond B Biol Sci 1972;180(1060):293-315. DOI: 10.1098/rspb.1972.0019.

31. Gathercole LJ, Keller A. Crimp morphology in the fibre-forming collagens. Matrix 1991;11(3):214-234. DOI: 10.1016/s09348832(11)80161-7.

32. Parry DA. The molecular and fibrillar structure of collagen and its relationship to the mechanical properties of connective tissue. Biophys Chem 1988;29(1-2):195-209. DOI: 10.1016/03014622(88)87039.

33. Franchi M, Quaranta M, Macciocca M, Leonardi L, Ottani V, Bianchini $\mathrm{P}$, et al. Collagen fibre arrangement and functional crimping pattern of the medial collateral ligament in the rat knee. Knee Surg Sports Traumatol Arthrosc 2010;18(12):1671-1678. DOI: 10.1007/s00167-0101084-6.

34. Kolenda K, Najbar A, Rozenblut-Kościsty B, Serwa E, Skawiński T. Common occurrence of Sharpey's fibres in amphibian phalanges. Zoomorphology. 2018;137(2):329-336. DOI: 10.1007/s00435-0180400-4

35. Spiesz EM, Thorpe CT, Thurner PJ, Screen HRC. Structure and collagen crimp patterns of functionally distinct equine tendons, revealed by quantitative polarised light microscopy (qPLM). Acta Biomater 2018;70:281-292. ISSN 1742-7061. DOI: 10.1016/j.actbio.2018. 01.034.

36. Francillon-Vieillot $\mathrm{H}$, de Buffrénil V, Castanet J, Géraudie J, Meunier $\mathrm{F}$ Sire JY, et al. Microstructure and mineralization of vertebrate skeletal tissues. Skeletal Biomineralizat: Patterns, Processes Evolution Trends 1989. pp. 175-234.

37. Aaron J. Periosteal Sharpey's fibers: a novel bone matrix regulatory system? Front Endocrinol (Lausanne) 2012;3:98. DOI: 10.3389/ fendo.2012.00098. 
38. Melcher AH, Eastoe JE. The connective tissues of the periodontium. In: Melcher AH, Bowen WH ed. Biology of the periodontium, London: Academic Press; 1969. pp. 167-343.

39. Ho SP, Marshall SJ, Ryder MI, Marshall GW. The tooth attachment mechanism defined by structure, chemical composition and mechanical properties of collagen fibers in the periodontium. Biomaterials 2007;28(35):5238-5245. DOI: 10.1016/j. biomaterials.2007.08.031.

40. Selvig KA. The fine structure of human cementum. Acta Odontol Scand 1965;23(4):423-441. DOI: 10.3109/00016356509007523.

41. Wang HM, Nanda V, Rao LG, Melcher AH, Heersche JN, Sodek J. Specific immunohistochemical localization of type III collagen inporcine periodontal tissues using the peroxidaseantiperoxidasemethod. J Histochem Cytochem 1980;28(11):12151223. DOI: $10.1177 / 28.11 .7000890$.

42. Jones SJ, Boyde A. The organization and gross mineralization patterns of the collagen fibres in sharpey fibre bone. Cell Tissue Res 1974;148(1):83-96. DOI: 10.1007/BF00224320.

43. Yamamoto T, Wakita M. Initial attachment of principal fibers to the root dentine surface in rat molars. J Periodontal Res 1990;25(2): 113-119. DOI: 10.1111/j.1600-0765.1990.tb00901.x.

44. Johnson RB. Synthesis of alveolar bone Sharpey's fibers during experimental tooth movement in the rat. Anat Rec A Discov Mol Cell Evol Biol 2005;284(1):485-490. DOI: 10.1002/ar.a.20179.

45. Glimcher MJ. Mechanism of calcification: role of collagen fibrils and collagen-phosphoprotein complexes in vitro and in vivo. Anat Rec 1989;224(2):139-153. DOI: 10.1002/ar.1092240205.

46. Glimcher MJ. Bone: nature of the calcium phosphate crystals and cellular, structural, and physical chemical mechanisms in their formation. In: Sahai N, Schoonen MAA, ed. Medical mineralogy and geochemistry, vol. 64, Chantilly, Virginia: The Mineralogical Society of America; 2006. pp. 223-282.

47. Freeman E, Ten Cate AR. Development of the periodontium: an electron microscopic study. J Periodontol 1971;42(7):387-395. DOl: 10.1902/jop.1971.42.7.387.

48. van Marion MM, Baaijens FP, Mol A, Merkx M, Rubbens MP. Matrix metalloproteinases and collagen remodeling a literature review. Division soft tissue biomechanics and engineering. Eindhoven Univer Technol 2006.

49. Gowen M, Wood D, Ihrie E, Meats JE, Russell RG. Stimulation by human interleukin 1 of cartilage breakdown and production of collagenase and proteoglycanase by human chondrocytes but not by human osteoblasts in vitro. Biochim Biophys Acta 1984;797(2):186-193. DOI: 10.1016/0304-4165(84)90121-1.

50. Kuhn K. The collagen family-variations in the molecular and supermolecular structure. Rheumatology 1986;10:29-69.

51. Welgus HG, Campbell EJ, Bar-Shavit Z, Senior RM, Teitelbaum SL. Human alveolar macrophages produce a fibroblast-like collagenase and collagenase inhibitor. J Clin Invest 1985;76(1):219-224. DOI: 10.1172/JCI111949.

52. Beertsen W, van den Bos T. Alkaline phosphatase induces the mineralization of sheets of collagen implanted subcutaneously in the rat. J Clin Invest 1992;89(6):1974-1980. DOI: 10.1172/ JCl115805.

53. Clark SD, Kobayashi DK, Welgus HG. Regulation of the expression of tissue inhibitor of metalloproteinases and collagenase by retinoids and glucocorticoids in human fibroblasts. J Clin Invest 1987;80(5):1280-1288. DOI: 10.1172/JCI113203.

54. Amenta PS, Gay S, Vaheri A, Martinez-Hernandez A. The extracellular matrix is an integrated unit: ultrastructural localization of collagen types I, III, IV, V, VI, fibronectin, and laminin in human term placenta. Coll Relat Res 1986;6(2):125-152. DOI: 10.1016/s0174-173x(86) 80021-8.

55. Kumada Y, Zhang S. Significant type I and type III collagen production from human periodontal ligament fibroblasts in 3D peptide scaffolds without extra growth factors. PLoS One 2010;5(4):e10305. DOI: 10.1371/journal.pone.0010305.

56. Huang YH, Ohsaki Y, Kurisu K. Distribution of type I and type III collagen in the developing periodontal ligament of mice. Matrix 1991;11(1):25-35. DOI: 10.1016/S0934-8832(11)80224-6.

57. Atkinson JC, Ruhl M, Becker J, Ackermann R, Schuppan D. Collagen VI regulates normal and transformed mesenchymal cell proliferation in vitro. Exp Cell Res 1996;228(2):283-291. DOI: 10.1006/excr.1996. 0328.

58. Sodek J, Limeback HF. Comparison of the rates of synthesis, conversion, and maturation of type I and type III collagens in rat periodontal tissues. J Biol Chem 1979;254(20):10496-10502. DOI: 10.1016/S0021-9258(19)86736-4.

59. Redlich M, Peleg I, Cooperman H, Shoshan S. Topological differences in the expression of collagen type I and collagen type III mRNAs in the rat gingiva. J Periodontol 1994;65(8):776-780. DOI: 10.1902/ jop.1994.65.8.776. 